\title{
15
}

\section{'Never Seen It Before': The Earliest Reports and Resulting Confusion about the Hagen Courting Dance}

\section{Don Niles}

The documentation of music and dance and the interpretation of such documentation are key elements in ethnomusicological research. In addition to doing one's own research, an ethnomusicologist is expected to be familiar with the relevant work of others in the same region or field of study. For music and dance researchers, such knowledge applies equally to photographs and audiovisual recordings, as well as more traditionally accepted published and unpublished textual sources.

My discussion here concerns the early documentation of a type of seated courting dance, distinctive to parts of the Highlands of Papua New Guinea. Initial descriptions of performances totally unfamiliar to the person recording them may often be highly fanciful or disparaging. In the case considered here, however, writings and photos clashed in fundamental ways, even when produced by the same author. How did such discrepancies arise? Do they reflect diachronically changing performance practices, faulty observations, or misinterpretations? 
This chapter also highlights the importance of research archives and libraries, for without the resources found in the National Archives of Australia (NAA) and, particularly, the National Library of Australia (NLA), the key sources to my investigation would have been unavailable to me. ${ }^{1}$

For me, the Australian location of these sources and the importance of the documentation itself also appropriately contribute to a celebration of the life and work of Stephen Wild. A very preliminary version of a part of this chapter was presented in 2010 at a symposium of the International Council for Traditional Music (ICTM) Study Group on Music and Dance of Oceania, organised by Stephen in Canberra entitled 'Tangible Records of the Intangible: Collecting Musical and Choreographic Culture in Oceania'. Indeed, my participation in the symposium gave me the opportunity to undertake follow-up research at the institutions mentioned above. ${ }^{2}$

ICTM has indeed provided many occasions for Stephen and me to interact. In 1988 (but certainly we met before then?), we both participated in the eighth ICTM colloquium held in Townsville, again with a theme concerning documentation. Since then, there have been Study Group symposia, many world conferences (including the memorable one in 2005 where he asked me on behalf of the Board to consider becoming his successor as editor of the Yearbook for Traditional Music while he became Secretary General), and quite a few Executive Board meetings. As I became more and more involved in increasingly diverse ICTM activities, Stephen was always there to give encouragement and offer advice whenever needed. He seemed infinitely knowledgeable and wise about all these things. My admiration has only grown.

In addition to honouring the professional support and encouragement Stephen has given me in my own research and as editor of the Yearbook and ICTM Board member, I also hope that this chapter goes some way towards acknowledging his constant enthusiasm, hospitality, generosity, and friendship. Thank you, Stephen.

1 I very much appreciate the assistance of the staff of the NLA and the NAA in helping me access and copy some of the materials used here. I also acknowledge the ongoing support of the Institute of Papua New Guinea that has enabled me to visit the Hagen area numerous times from 1982 onwards to consult with people there over issues discussed in this chapter.

2 This research also enabled a further revision presented at the 2011 ICTM world conference, held in St John's, Newfoundland, Canada. 


\section{Highlands courting traditions}

The descriptions I consider below are the first of a courting tradition that is found in parts of all seven Highlands provinces of Papua New Guinea (e.g. see the map in Niles 2011: 430, fig. 8-14). ${ }^{3}$ Such courting is one of the main socially acceptable ways to meet and interact with members of the opposite sex in these areas. They are public occasions, not clandestine liaisons. Many ethnographic reports emphasise the fact that girls make many decisions regarding such courting: the time and place, whom to invite and to court, whether the relationship should continue, etc. These activities are almost universally for unmarried females, on the one hand, and unmarried or married males looking for additional wives, on the other. Courting is for males and females together, usually performed by couples who are sitting or lying down, but never standing. Often the performance allows courting couples to change partners frequently during the night. The occasions are generally chaperoned by older women.

Most Highlands courting is done indoors at night. Although singing appears to be universal at such events, no instruments are used. Courting frequently involves dancing or some sort of special body contact between those courting. This body contact is 'special' because it is usually quite different from what would otherwise be deemed acceptable physical interactions and also contrasts (often dramatically) from the choreography found in other dances. Highly variable elements across the region relate to the type of movements used; the orientation of the performers to one another; the touching of parts of the face (foreheads, chins, cheeks, noses, etc.), hands, or legs; the possible separation of dancers from singers, and the number of people participating. ${ }^{4}$

The particular courting traditions considered here are those found in parts of the Mount Hagen area in Western Highlands Province of Papua New Guinea. Four Hagen languages or parts of a language chain are recognised in the most recent version of Ethnologue (Lewis et al. 2016): Melpa, Bo-Ung, Imbongu, and Umbu-Ungu. In this chapter, I refer to this region generally as the 'Hagen area', although the descriptions are most often focused on regions speaking the Bo-Ung and Melpa languages.

3 Although apparently no longer performed in some areas, performance activity throughout the entire region remains uncertain so I write about these traditions in the present tense.

4 For further information about Highlands courting traditions, see Stewart and A. Strathern (2002) and Niles (2011: 158-83, 428-66). 
The Papua New Guinean dances that Europeans would have encountered up until this time tended to be performed outside by singing dancers moving on their feet and often playing or accompanied by instruments such as drums, slit-drums, flutes, and rattles. Dances associated with men's cult activities might indeed be performed inside, but otherwise resembled public dances. As a result, it is not surprising that when first seeing a Highlands courting dance, one of the expedition members wrote: 'never seen it before'.

\section{Leahy's published descriptions of a Hagen courting dance}

In the 1937 book The Land that Time Forgot: Adventures and Discoveries in New Guinea, explorer Michael 'Mick' Leahy and ghostwriter Maurice Crain describe Leahy's 1933 encounter with a seated courting dance, performed in what is today the Mount Hagen area:

We noticed a rather remarkable nose-rubbing custom among the natives here, the significance of which none of us could guess. Two of the men would sit facing each other, swaying from side to side and humming a monotonous tune. By slow degrees their heads would approach each other until the noses touched, and they would continue swaying and humming in unison for several minutes, after which both participants would appear dazed and half asleep, wearing a fixed smile. The effect rather suggested hypnosis. I later noticed this custom among some of our neighbours near Mt. Hagen, but they seemed reluctant to discuss it. I have seen several couples engaged in this performance at the same time. (Leahy and Crain 1937a: 202; 1937b: 190)

It is unclear whether this description refers to one observation or summarises observations of a number of such performances.

Leahy and Crain's description is accompanied by a photograph captioned 'Nose-rubbing Ceremony on the Nabilya'. It appears in both the New York (1937b: opp. p. 192) and London (1937a: opp. p. 160) editions of the book, although in the latter it is more tightly cropped to feature the pair of dancers in the centre.

The photograph shows two men, seated face to face, with their foreheads and noses touching. They are performing outside, during the day. While the description and the photograph might be considered conclusive documentary evidence of the performance tradition at first contact with 
Europeans, they are in striking variance with other contemporary reports and present-day practice, where courting is performed inside a house, at night, and by seated pairs of male and female dancers.

This chapter considers the first documentation of this dance during the earliest years of contact between Hageners and Europeans, particularly how early reportage presented contrasting reports. Important lessons can be learned about the necessity of considering all available sources in any such historical pursuit.

This short, written description and the accompanying photograph provide many possible features for consideration, for example, the seated dancers and their orientation to each other; the choreographic movements; the 'humming'; the 'monotonous' melody; the demeanour of the performers; the contexts for such performances. Some of these provide invaluable comparative data to consider with other reports and modern practice.

For the purposes of this chapter, however, I am concerned with three rather straightforward features: where (inside or outside) and when (diurnal or nocturnal) the dance is performed, and the gender of the performers (exclusively male, or male and female). These would seem to be rather basic observational details that could easily be provided without any knowledge of the context of the event. Yet, I have singled them out precisely because of the confusion surrounding them when considering other reports.

Mick Leahy (1901-1979; Figure 1) and his brother, Dan (1912-1991), were part of an expedition searching for gold for the New Guinea Gold Company, and the company also provided a surveyor, Ken Spinks (19101943). The expedition leader was Jim Taylor (1901-1987), a government patrol officer based in Kainantu, in present-day Eastern Highlands Province. They were accompanied by seven armed police constables, a medical orderly, two government assistants, two personal servants, and 30 carriers. ${ }^{5}$ While Taylor wrote the official report of the trip, Mick Leahy documented it in his diaries, photos, and movies; resources that he later drew on for a number of articles and books. The film First Contact (Connolly and Anderson 1983) uses his movies as the starting point for a documentary on their historic travels. ${ }^{6}$

5 While there are varying accounts of the numbers involved (e.g. Ketan 2004: 82-83, n. 7), these figures are taken from the official report (Taylor 1933: 27).

6 See also the eponymous book about the film and the expedition (Connolly and Anderson 1987). Further information about Mick Leahy and the Leahy family can be found there, as well as in Ashton (1978), Jones (1994a), and Griffin (2006). 


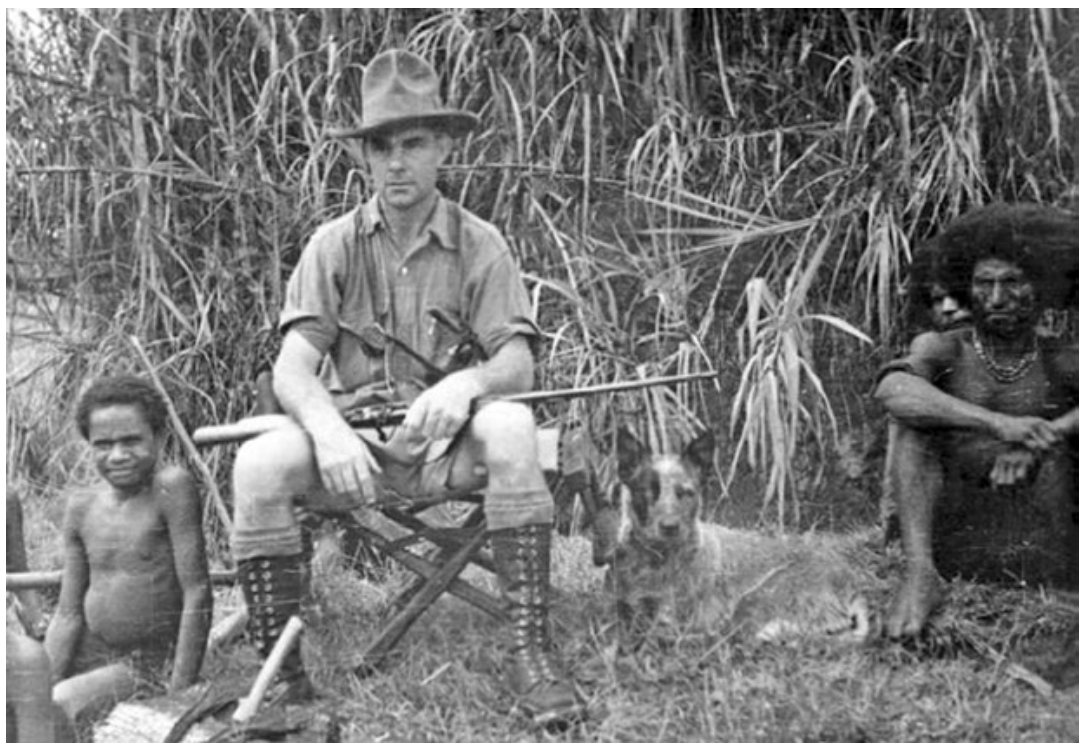

Figure 1. Michael Leahy in the Wahgi Valley, 1934

Source: Leahy 1933-34: PIC/6102 Roll 85 A3/23 LOC ALBUM 801/24

Their expedition lasted from 28 March to 19 October 1933, and was well supported by reconnaissance flights and landings at airstrips built on the spot. It took them through parts of most of the present-day Highlands provinces. ${ }^{7}$ This expedition revealed something of the huge population that was mostly unknown to the Australian colonial powers at the time, and eventually helped open up the Wahgi Valley region to various economic developments. ${ }^{8}$

In 1935, Leahy travelled to London, giving a presentation on 5 November to the Royal Anthropological Institute using film and lantern slides he had taken in the Hagen area. A brief mention of his presentation in Man notes Leahy's use of illustrations of 'nose-rubbing ceremonies (men and women in pairs)' (Leahy 1935: 185). Note that here the paired dancers are described as men and women, rather than just men, as in The Land that Time Forgot. On 21 November, Leahy made what was probably a similar presentation of photos and moving pictures to the Geographical Society, also in London (Hinks 1936: 226).

7 For maps of the expedition route, see Spinks (1936), Hinks (1936), and Souter (1964: 58, map). 8 Hays's masterful introduction to early anthropological work in the Highlands (1992) is also a valuable introduction to the gradual expansion of European presence there. 
Confusing the matter even further, 57 years after Leahy and Crain's first published description, another report by Leahy of this encounter was published. Although Leahy had died 15 years earlier, the editor of the volume claimed that Leahy had compiled the book in the 1960s from his 'daily fieldnotes' (Jones 1994b: xi), undoubtedly meaning his diaries. At odds with his 1937 description, here it is very clear that the dance is performed by a male and female, inside a house, and at night:

Here for the first time we saw a kunnunna, or courting get-together of the young women, young men, and not so young men, who were greased, painted, and decorated with feathers. The meeting place was a long house. A couple of fires gave off some light and great heat in the enclosed space. A man and a girl sat facing each other. To the subdued hum of a rather dirgelike song they gradually swayed their bodies from side to side, and moved forward until their noses touched. The head movement became a cheek-nose-cheek contact. They smeared each other with their pig grease and paint and disarranged their decorations. Seeing our interest, our Hagen people promised to take us to another such ritual when we were back in base camp. It is essentially a night ceremony, and the Hagen people were not as reserved in its performance as these newly contacted semibush natives were. Nose rubbing advances to leg rubbing, the personal adornments and covering became disarranged, and the couple dashed outside to consummate the sing-sing despite the not very convincing remonstrations of the aged crones who acted as chaperones. (Leahy 1994: 128-29)

How did the discrepancies in describing what is presumably the same event by the same author occur between 1937 and 1994? As will be seen below, the answer appears to be much more complicated than just a change of perspective or hindsight.

\section{Other contemporary descriptions of Hagen courting}

Leahy and Crain's 1937 description was actually not the first available report of the courting. In his official report of the expedition, ${ }^{9}$ now found in the NAA, Jim Taylor describes Hagen courting as follows:

9 Perhaps not actually published, but it was written for an official purpose and made available to others. 
At night in the houses after the evening meal, the family and guests sit by the fire and sing dreamy songs. The singers of both sexes sway and lean towards each other, until their noses touch, then with noses apparently locked together, they roll from side to side singing. Their eyes are closed and they appear as if intoxicated. After several minutes they return to normal sitting postures, and rest before repeating the performance. (Taylor 1933: 65)

Since this is not linked to a specific date, it is unclear whether this description refers only to a single observation of this dance or generalises about numerous performances witnessed during the course of the expedition. Nonetheless, here the performers are male and female, inside a house, and at night, all features of present-day practice, but at odds with the account by Leahy and Crain. Indeed these details coincide much more closely with Leahy's 1994 report.

E. W. P. Chinnery, former government anthropologist and Taylor's boss as the Director of District Services and Native Affairs for the Territory of New Guinea, visited the expedition near Mount Hagen between 30 June and 1 July 1933. Chinnery's article only paraphrases what Taylor reported:

Taylor describes an interesting ceremony which he saw in one of the houses after the evening meal. Males and females sat by the fire and sang dreamy songs, the sexes swayed and leaned towards each other until their noses touched, then with noses apparently locked together, they rolled from side to side with their eyes closed in evident ecstasy. After a few minutes they would return to their normal sitting position and rest before repeating the performance. (Chinnery 1934: 121)

Except for a change in tenses and the appearance of the dancers being described 'as if intoxicated' by Taylor and 'in evident ecstasy' by Chinnery, the descriptions are almost exactly the same. Chinnery's is actually the first published reference to the Hagen courting dance.

As the Hagen region concerned straddled the border between the two territories, it was of interest to anthropologists from both. On 31 January 1936, F. E. Williams, government anthropologist for the Territory of Papua, arrived in Mount Hagen where he then spent 'three otherwise unoccupied afternoons and evenings to see something of the natives of the district' (Williams 1937: 90). Williams's short mention of Hagen courting confirms the account previously given in Chinnery's article that ultimately derived from Taylor's 1933 report: 
We visited this [women's] house in the evening, when the outer room was lined with men and women singing and watching a performance of the peculiar nose- or forehead-rubbing ceremony described in Chinnery's article. (Williams 1937: 95)

In 1934, the year following initial contact, both Catholic and Lutheran missionaries settled in the Hagen area. In a general ethnographic overview, Fr William Ross, SVD, described the courting dance:

Generally young men do not go visiting young women of other places, except at night when the singsing kanana is held. This takes place in the women's house. The mother of the girls builds a big fire in the fireplace and by the light of this the couples sit on the floor facing one another, noses touching and heads weaving back and forth in imitation, apparently, of wooing birds. (Ross 1936: 358)

In the following year, he published a popular account in a mission magazine concerning a performance in July 1936:

This is a sort of love-making carried out at night, boy and girl rubbing noses and foreheads together to the chanting of the onlookers. (Ross 1937: 66)

Quite clearly, Ross describes nocturnal, indoor performances by males and females.

Lutheran missionary Georg Vicedom also wrote an early description of courting:

Der Tanz findet nur nachts statt. Der Freund des Mädchens kommt mit einer Anzahl Männer in das Haus des Mädchens ... Das Mädchen sitzt in der Mitte, auf der einen Seite läßt sich der Freund nieder, auf der anderen Seite ein anderer Mann. Nun beginnt das Mädchen mit dem Freund Kopfrollen ... Zuerst rollen beide unabhängig voneinander, je länger es dauert, desto näher kommen die Köpfe zusammen bis die Stirnen aufeinander liegen und sie gemeinsam rollen. Zuletzt reiben sie nur noch die Wangen und die Nasen aneinander. ${ }^{10}$ (Vicedom 1937: 192)

10 'The dance only takes place at night. The [male] friend of the girl comes with a number of men to the girl's house ... The girl sits in the middle; on one side her friend sits down, on the other side another man. Now the girl begins to roll heads with the friend ... At first both roll independently of one another; the longer it continues, the closer the heads come together until their foreheads touch each other and they roll them together. Finally they rub only their cheeks and noses together' (my translation). 
Vicedom also clearly describes indoor performances at night involving both genders. ${ }^{11}$

Dating from the first four years after Europeans first entered the Hagen area, all of the early descriptions noted in this section are by the first Europeans to see these dances, anthropologists who collaborated with them, or missionaries who arrived shortly after this initial contact and subsequently settled in the region. All of these and even later reports are at odds with the 1937 account by Leahy and Crain. ${ }^{12}$

The keys to understanding these discrepancies lie in two collections of material from Mick Leahy now archived in the NLA. Aside from helping to resolve these conflicts, the collections contain a wealth of invaluable information about this period of early contact.

\section{Leahy's diary description}

The NLA contains numerous materials from Mick Leahy, amongst them the diaries he used during his expeditions, 1930-34 (Leahy 1930-34). ${ }^{13}$ His unpublished diary entry for Saturday, 22 July 1933, is the first written description of any type of Highlands courting dance. ${ }^{14}$ It describes an event that he and the others had witnessed the previous night (Figure 2):

11 Vicedom later co-authored with Herbert Tischner a major ethnography on the Hagen area in which they detail much more about such courting (e.g. Vicedom and Tischner 1943-48: 1/244-45, 247 [1983: 276-77, 279-80], 2/190-97; 3/42). Other valuable accounts of various aspects of Hagen courting are given by A. Strathern and M. Strathern (1971: 38-43), Eibl-Eibesfeldt (1974, 1986), Pitcairn and Schleidt (1976), Brandewie (1981: 91-94), A. Strathern (1985: 124-25), Stewart and A. Strathern (2002: 47-69), and Niles (2011: 158-83).

12 Vicedom and Tischner (1943-48: 2/192) would later note Leahy's description of two men dancing, but instead of discrediting or correcting it, they simply comment that they did not know of such a tradition: since Leahy was reporting on an area to the south of where the missionaries were working, it was certainly possible that the tradition was different there.

13 In 2008, Jeanette Leahy kindly granted me permission to consult her husband's diaries in the NLA. Although many others had preceded me, I was the last to be granted such permission as shortly thereafter restrictions were lifted on access to them. The NLA then very kindly mailed me microfilms of the diaries, which I was only able to examine (with considerable difficulty) on a microfiche reader made available by Elizabeth Lopa at the Adventist Heritage Centre of Pacific Adventist University. In 2010 I revisited the NLA with the hope of viewing the microfilms again, but on a proper microfilm reader. Much to my surprise and delight, library staff asked if I wouldn't prefer to examine the original materials. Of course I agreed and was thrilled to also be able to take photographs of relevant entries. In 2016, Mick and Jeanette's son, Phillip Leahy, granted me permission to quote from the diaries and to use the photo of them for this chapter.

14 The dating of this event also explains why Chinnery had to rely on Taylor's account of courting: Chinnery's visit predates the expedition's first encounter with the dance. 
Rained very heavy during early part of night and the local natives gave us an exhibition of their particular sort of a sing sing in their house. They hummed a song and while in a sitting position moved their heads from side to side slowly while facing his partner who also done the same. They gradually worked closer together and touched their noses together then swayed together while rubbing their noses together. Never seen it before and don't know what the strength of it is. ${ }^{15}$ (Leahy 1930-34: diary entry, 22 July 1933)

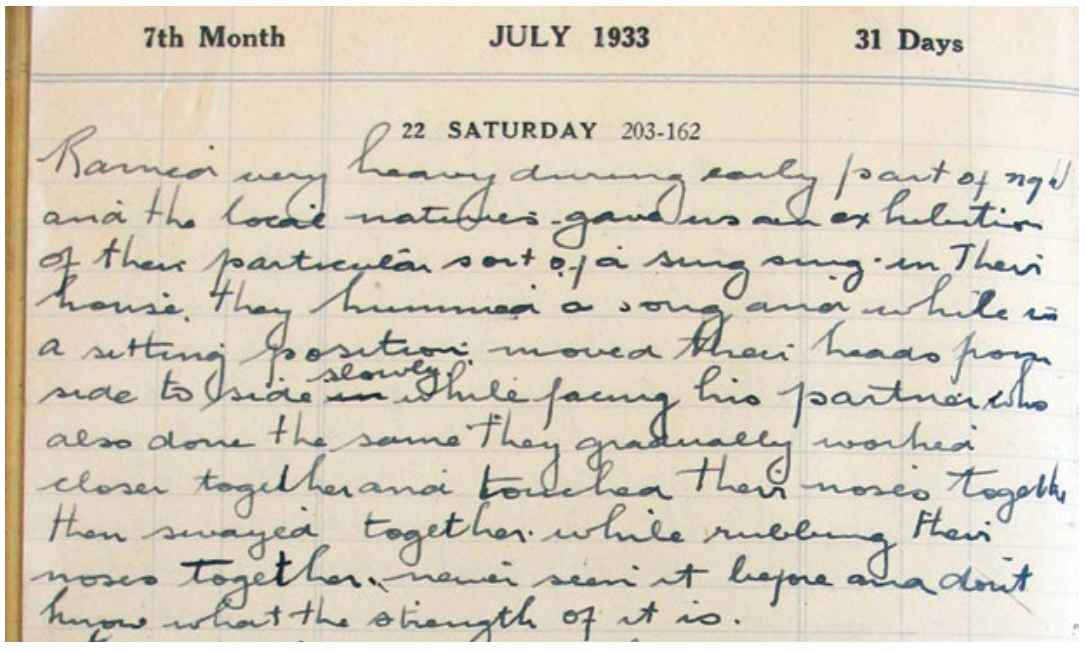

Figure 2. The beginning of Mick Leahy's diary entry for 22 July 1933 describing the expedition's first encounter with Hagen courting

Source: Leahy 1930-34

Leahy describes a traditional song/dance performance, here referenced by the Tok Pisin (New Guinea Pidgin) word 'sing sing'. ${ }^{16}$ Crucial aspects of this description are the dance took place inside a house at night; the performers 'hummed' a song; ${ }^{17}$ they danced as pairs, in a seated position, facing each other, and moving their heads from side to side; their faces

15 Leahy's handwriting is not particularly clear in this entry: dots for a lower-case $i$ might instead be meant as full stops, and there is inconsistency in capitalising the first letter of sentences. Although such details may result in slightly different transcriptions, they are not of any great significance to my interpretation.

16 Now usually written singsing. Despite the unusual performance he observes, Leahy readily identifies it as a singsing, rather than something else. Certainly the movements would have been quite unlike anything he had previously experienced as dance. Perhaps it was the 'hummed song' that led to such an evaluation.

17 Although not considered in further detail here, this reference to humming may be to the common and distinctive use of repeated vocables in many songs in the Hagen area. See Niles (2011: 77-78, 425-28). 
moved closer together and eventually they touched and rubbed their noses together, while continuing to sway together. While any of these elements might be noteworthy, especially in contrast to the types of Papua New Guinean dance Leahy would presumably have been exposed to before or even his own acquaintance with Western styles of dance, it is likely that it was the seated dance movements with touching faces that struck him the most. He didn't know the strength (i.e. meaning) of it.

The diary entry makes it quite clear that the performance takes place at night inside a house. From the written reference to 'his partner', we know that one of the dancers is male, but the gender of the partner is unstated.

Leahy's lack of understanding the meaning of what he was witnessing is hardly surprising as no one in their group could understand the language spoken in the Nebere (Nebyer, Nabilya, Nebilyer) River area, ${ }^{18}$ where they saw the performance. Nevertheless, the elements I am focusing on here (where, when, by whom) do not require knowledge of the performers' language for further enlightenment at all; hence, the confusion surrounding descriptions cannot be explained as due to Leahy's ignorance of contextual details. The description here corresponds well with all reports except that by Leahy and Crain in 1937 . What happened between this diary entry and the publication of The Land that Time Forgot? The answer appears to lie with Leahy's photographs and the work of creating the book that would make use of them.

\section{Leahy's photographs}

Although conflicting with almost all other reports, particularly compelling evidence over the nature of courting performances would seem to be the photograph used in Leahy and Crain's book. This particular photo is one of a series of at least eight in Leahy's collection at the NLA (Leahy 193334: V4/1-8). ${ }^{19}$ Leahy took photography seriously, using a Leica camera and, at least for this series, Perutz film, one of the first companies to make film for such cameras. ${ }^{20}$

18 According to Ethnologue (Lewis et al. 2016), the language is Bo-Ung.

19 The reference numbers used here correspond to those on the cards on which individual contact prints are mounted and annotated. A separate contact sheet for what might be the entire roll shows the numbers on the negatives to be 7-14.

20 See Connolly and Anderson (1987: 93-99) for more on Leahy and his involvement with photography at this time. 
All of these photos are labelled as from the 'Mt. Hagen Base Camp' and dated to 1934. However, Leahy's diary entry of 10 September 1933 notes: 'Cooled off in the camp and developed a film. The nose rubbing came out good' (Leahy 1930-34: diary entry, 10 September 1933). The photos referred to were taken less than two months after seeing the first performance of the courting dance, but whether these are the photos now housed in the NLA or others as yet unidentified remains uncertain (Figure 3). ${ }^{21}$

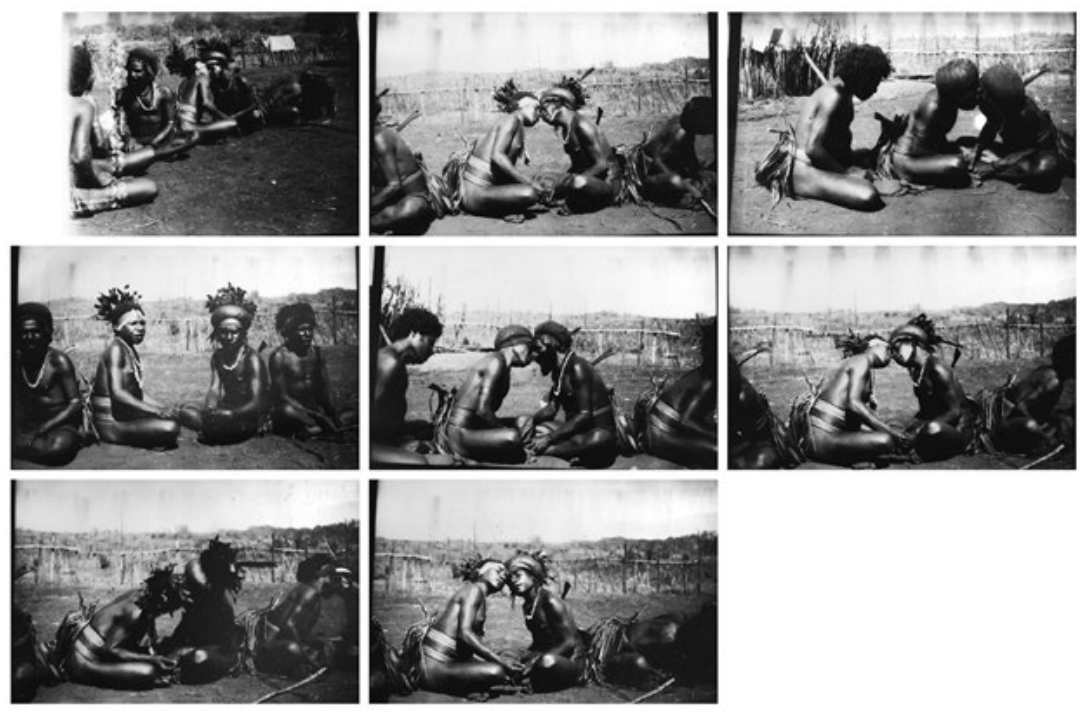

Figure 3. Contact prints of Leahy's eight photographs of courting Source: Leahy 1933-34: V4/1-8

The photo used in publication is the same as the second one in the sequence here (i.e. the middle photo in the top row). Whether they were taken in September 1933 or in the following year, the photos in the NLA are not of the first performance in the Nebilyer Valley in July 1933.

Rather, the photos appear to be back at the Hagen camp: it can clearly be seen that there is a wooden fence in the background. Such fences were constructed at camps to separate local people from the visitors. It is likely that the performance took place during the day so that photographs could

21 I created this figure from the individual photos I took of the mounted contact prints at the NLA. Because these cards could not lie flat, some warping of the images results; nevertheless, this figure gives an idea of photos concerned and are sufficient for my discussion here. 
be taken: it does not appear that Leahy had a flash, which would have enabled him to take photos inside a crowded house during a night-time performance. Finally, these performances were done by pairs of men, not because this was the tradition, but because women generally would have been kept at a distance from visitors: initial contacts were made by men, with women frequently kept at a distance from the newcomers. The photographs recorded a demonstration of the movements of the courting dance, although incorrect in context, place, time, and gender of the performers involved. The demonstration/performance photographed by Leahy can be seen as an indication of Hageners' desire to modify their traditions in order to display them to others. The demonstration was also of a type of performance the men truly enjoyed and thought that their visitors would too. At this time of contact, communications were mostly through gesturing, so any explanations or corrections were just about impossible. Hence, rather than documenting an earlier tradition and providing evidence of diachronic change in choreographic practice, the discrepancies from present-day practice result from something much more mundane: the contact situation itself. For all these reasons, the caption from the Leahy and Crain book-'Nose-rubbing Ceremony on the Nabilya - would appear to be incorrect.

At least seven different men are identifiable in the photos, ${ }^{22}$ which show the dance being performed by pairs of males (rather than a male and female), outside (rather than inside), and during the day (instead of at night).

In the NLA, contact prints of these photographs from Leahy's collection are mounted on individual cards. The most extensive written text is found on two of these cards:

Nose to nose. Kunnunar / This is a man-mary ${ }^{23}$ / night time sing sing / Mt Hagen. (Leahy 1933-34: V4/1)

Kunnunar. Nose to nose / Boy to girl. Night sing sing / Mt Hagen.

(Leahy 1933-34: V4/4) (Figure 4)

22 In my research, Hagen elders were unequivocal in their identification of the performers as all men. Aside from physical features such as beards and breast size, this was clear from the male style of dress. 23 Man and mary (meri in current orthography) are the Tok Pisin terms for man/male and woman/ female, respectively. 


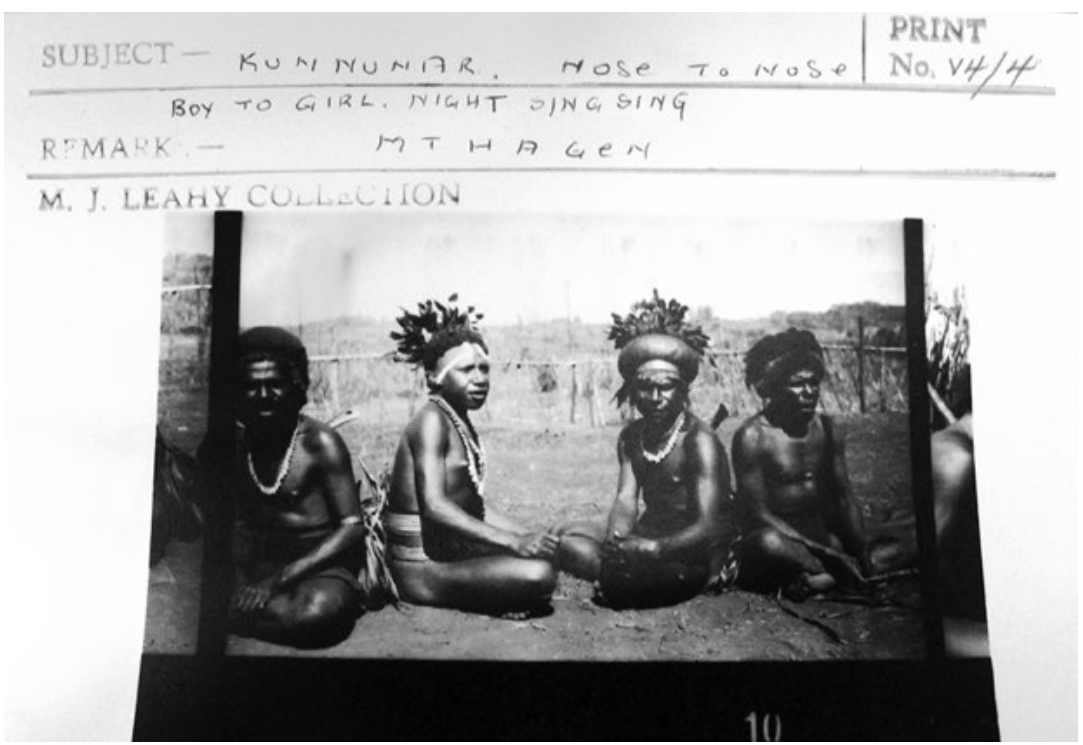

Figure 4. Annotated card with information about courting

Source: Leahy 1933-34: card for V4/4

It is not known when these annotations were made, nor by whom. Here 'kunnunar' is the annotator's spelling of kunana, ${ }^{24}$ the local generic term for any type of singing or dancing. Courtship dancing here is typically called amb kunana 'woman song'. ${ }^{25}$ Additionally, the annotations make it perfectly clear that the dance is performed by a male and female at night, contrary to the photographs' portrayal of performances by two male performers during the day. Once again, there is conflicting information, here between photos and their captions.

In summary then, where such details are recorded, written sources by Leahy and his contemporaries all note an inside performance at night, but his photos show one outside during the day. These photos and Leahy and Crain's 1937 description in The Land that Time Forgot also portray pairs of male dancers, while all other sources note male-female pairs. The main issues of difference appear to be between Leahy's photos coupled with his and Crain's 1937 description, on the one hand, and all other sources, on

24 Taylor (1933: 91) writes the word for 'sing' in a related dialect as ga-nan (cf. Melpa kenan 'song').

25 The more commonly encountered term in Hagen ethnographies is amb kenan, in the Melpa language. 
the other. Performers today make no hesitation in confirming the latter set of features. They deny that there is any earlier performance tradition being documented.

Even though it is impossible to supply all the missing pieces of information to work out a sequence of what happened in writing up the descriptions of these events, it is still possible to suggest a likely scenario that would lead to the present sources.

\section{Considering all the sources}

It is certain that Leahy's diary entry of 22 July 1933 documents the expedition's first encounter with the courting dance. The first major differing information after this source is Leahy's photos. Although there is some conflicting evidence in his diaries, the NLA records note that at least some of Leahy's photographs of the dance were made in 1934, after the conclusion of the expedition, when Leahy and others would have revisited to the Hagen area.

Leahy took some of his photographs along with him on his visit to London in 1935. Furthermore, in order to collaborate with Maurice Crain on The Land that Time Forgot, it is very likely that Leahy relied on his diaries and his photos. Crain ${ }^{26}(1901-1970)$ was apparently regarded as an experienced American ghostwriter at the time. He would later become a well-known literary agent in collaboration with his wife, motion picture agent Annie Laurie Williams (1894-1977). Together they represented authors such as Truman Capote, Harper Lee, Margaret Mitchell, and John Steinbeck (Connolly and Anderson 1987: 20; Jones 1994a: 245; Fowke 1995: 158, 162-63). ${ }^{27}$

We will probably never know how Leahy and Crain collaborated on this book, leaving many crucial questions unanswered. How closely did they work? How much consultation and clarification was sought and supplied during the writing? Did Leahy leave his diaries and photos with Crain

26 Jones, editor of one of Leahy's later books, misspells Crain's surname as 'Crane' (Jones 1994a: 245).

27 Crain and Williams's subsequent essential role in the evolution of Harper Lee's 1960 novel To Kill a Mockingbird has received particular attention in recent articles (Schulman 2015; Seal 2013; Ticker 2015). Aside from his co-authorship with Leahy, Crain initially appeared to be a rather shadowy figure; only through the wonders of googling have his wider associations become known to me. 
to construct the narrative? Were there cross-references between the two sources to assist Crain in this work? Whatever the arrangement may have been, the result was published and made widely available.

Certainly their description of the first encounter with the courting dance seems to rely upon the diary, but with details as to the gender of the dancers being supplied by the photos. Interestingly, the written description contains no details on where or when the performance takes place. Perhaps this is because the diary description of an inside, night-time performance is contradicted by the photos showing an outside, daytime one, and it would have been difficult for Crain to resolve such issues without Leahy's explanations. Or perhaps Leahy was available and simply relied upon the photos, rather than his diary or his memory.

As other subtle differences, the 1933 diary entry refers to a dance ('sing sing') and the humming of a 'song'. The 1937 description, however, refers to a 'custom' or 'performance', with no mention of it being a dance, and here the humming is of a 'monotonous tune', rather than a song. These changes perhaps result in a slightly condescending tone.

Sometime well after their collaboration on the book, Leahy must have donated his materials to the NLA. Contact prints of his photos were eventually provided with written descriptions, and some of these for the courting performance at least differed from what was portrayed in the photo, without any indication as to the reason for the discrepancies. ${ }^{28}$

When Leahy went through his diaries again, compiling a book in the 1960s that would not be published until 1994 as Explorations into Highland New Guinea, 1930-1935, it was an opportunity for him to expand upon what was in the diaries, updating and correcting where necessary. Consequently, the information contained there relies upon the diaries, but now gives the courting performance a name: kunnunna, very similar to the kunnunar used in captions for contact prints of his photographs in the NLA. More significantly for the purpose of this chapter, further information is given about the performance, particularly that it takes place inside at night and by a man and girl. Finally, Leahy

28 Communication from Joshua Bell from the NLA (29 February 2016) notes that most of the Leahy materials were obtained in June 1955, with some additional 1930s photographs added in 1971. More detailed information is unavailable. 
notes that the Hageners who had accompanied them promised to perform it again back at the base camp. Perhaps this later eventuated, enabling the photographs to be taken.

The description and photograph of courting in Leahy and Crain's book appear to be a combination of misremembered details, haste, and erroneous conclusions, perhaps in the absence of Leahy, but presumably with his consent. As more people wrote about the dance, these issues were quickly overwhelmed by contrary evidence. Nevertheless, as the information derives from Leahy, one of the first outsiders to see the dance, it is important to try and explain these differences.

\section{Conclusions}

Leahy and Crain's 1937 book The Land that Time Forgot made Leahy's travels, explorations, and encounters available to a worldwide audience. At least in their description of a Hagen courting dance, however, there were differences that conflicted with subsequent publications by Leahy and others. Examination of unpublished written and photographic material by Leahy and others in combination with the statements of Hagen elders suggests that rather than documenting changes in performance style, the 1937 report was simply wrong in certain details, and that the photograph accompanying it was from a specially enacted performance situation, made for the visitors, rather than a reflection of local tradition at the time.

Such variations from correct practice for the purpose of documentation were hardly unique to that situation. In 1955, Beth Dean and Victor Carell also photographed Hagen courting being performed outside and during the day, undoubtedly also to enable photos to be taken (e.g. Dean and Carell 1958: 138-39 (photos)).

And in 2004, 71 years after the first written record of the Hagen courting dance, my colleague Balthazar Moriguba and I made photographs and audiovideo recordings of this same dance, also in the Nebilyer area. The number of people present required that the performance take place outside as houses were not big enough to hold performers, researchers, and other observers. And because many of the local girls were too closely related to the boys who wanted to dance, some of the boys dressed as girls and danced, just to demonstrate the choreography. While we knew why 
these changes were made and what was considered the correct performance context, this is a comparable example of how some performance elements can be changed for the purpose of a demonstration.

Caution must be practised with any sources, particularly those from early contact situations dealing with unfamiliar events. Descriptive information that conflicts with practices today may indicate errors of observation, diachronic changes, or simply confusion when writing up the events for publication. Doing thorough library and archival research demands familiarity with all sources in text, photos, and audiovisual recordings, published and unpublished. Only then can they be properly evaluated and better understood.

\section{References cited}

Ashton, Christopher. 1978. 'The Leahy Family.' In Papua New Guinea Portraits: The Expatriate Experience, edited by James Griffin, 169-94. Canberra: Australian National University Press.

Brandewie, Ernest. 1981. Contrast and Context in New Guinea Culture: The Case of the Mbowamb of the Central Highlands. Studia Instituti Anthropos, 39. St Augustin: Anthropos Institute.

Chinnery, E. W. P. 1934. 'Mountain Tribes of the Mandated Territory of New Guinea from Mt. Chapman to Mt. Hagen.' Man 34 (August): 113-21. doi.org/10.2307/2790019.

Connolly, Bob, and Robin Anderson. 1983. First Contact. Colour, $16 \mathrm{~mm}$, $101 \mathrm{~min}$. film (Included in The Highlands Trilogy: The Complete Collection. 3 DVDs. Australian Broadcasting Corporation 105136-9. 2005.) (IPNGS c08-017, ${ }^{*} 1$ ).

—— 1987. First Contact. New York: Viking Penguin.

Dean, Beth, and Victor Carell. 1958. Softly, Wild Drums: In New Guinea To-day. Sydney: Ure Smith.

Eibl-Eibesfeldt, Irenäus. 1974. 'Humanethologisches Filmarchiv der MaxPlanck-Gesellschaft HF 57-59: Medlpa (Mbowamb)-NeuguineaWerberitual (Amb Kanant).' Homo 25: 274-84. 
- 1986. Melpa (Ost-Neuguinea, Zentrales Hochland)_Werbetanz ('amb kenan' / 'tanim het'); Medlpa (East New Guinea, Central Highlands)—Courtship Dance ('amb kenan'/ 'tanim het'). Encyclopaedia Cinematographica E 2871. Institut für den Wissenschaftlichen Film. Colour film, 15 1/2 minutes.

Fowke, John. 1995. Kundi Dan: Dan Leahy's Life among the Highlanders of Papua New Guinea. St Lucia: University of Queensland Press.

Griffin, James. 2006. 'Leahy, Michael James (Mick) (1901-1979).' Australian Dictionary of Biography. Online edition. Canberra: The Australian National University. www.adb.online.anu.edu.au/biogs/ A100032b.htm.

Hays, Terence E. 1992. 'A Historical Background to Anthropology in the Papua New Guinea Highlands.' In Ethnographic Presents: Pioneering Anthropologists in the Papua New Guinea Highlands, edited by Terence E. Hays, 1-36. Studies in Melanesian Anthropology. Berkeley: University of California Press. (Available on web: ark.cdlib.org/ark:/ 13030/ft2d5nb160/).

Hinks, Arthur R. 1936. 'Note by the Editor accompanying the Preceding and Following Papers.' Geographical Journal 87/3 (March): 226-28.

Jones, Douglas E. 1994a. 'Editor's Afterword.' In Explorations into Highland New Guinea, 1930-1935, by Michael J. Leahy, edited by Douglas E. Jones, 245-50. Bathurst: Crawford House Press.

—.1994b. 'Editor's Preface.' In Explorations into Highland New Guinea, 1930-1935, by Michael J. Leahy, edited by Douglas E. Jones, xi-xiii. Bathurst: Crawford House Press.

Ketan, Joseph. 2004. The Name Must Not Go Down: Political Competition and State-Society Relations in Mount Hagen, Papua New Guinea. Suva: Institute of Pacific Studies, University of the South Pacific.

Leahy, Michael J. 1930-34. 'Diaries and Speeches, 1930-1934.' National Library of Australia, Canberra, MS 384. 7 vols and 1 folder (also on 2 microfilms as: Mfm G 24753-G 24754). catalogue.nla.gov. $\mathrm{au} / \operatorname{Record} / 2665248$. 
1933-34. 'Collection of Photographs of New Guinea.' National Library of Australia, Canberra, PIC Albums 801/1-28. catalogue.nla. gov.au/Record/1585697.

_- 1935. 'Stone Age Peoples of the Mount Hagen Area, Mandated Territory of New Guinea.' Man35: 185-86. doi.org/10.2307/2789411.

- 1994. Explorations into Highland New Guinea, 1930-1935. Edited by Douglas E. Jones. Bathurst: Crawford House Press.

Leahy, Michael J., and Maurice Crain. 1937a. The Land that Time Forgot: Adventures and Discoveries in New Guinea. London: Hurst and Blackett.

- _. 1937b. The Land that Time Forgot: Adventures and Discoveries in New Guinea. New York: Funk and Wagnalls.

Lewis, M. Paul, Gary F. Simons, and Charles D. Fennig. 2016. eds. Ethnologue: Languages of the World. 19th ed. Dallas: SIL International. www.ethnologue.com.

Niles, Don. 2011. 'Structuring Sound and Movement: Music and Dance in the Mount Hagen Area.' PhD diss., University of Papua New Guinea.

Pitcairn, Thomas K., and Margret Schleidt. 1976. 'Dance and Decision: An Analysis of a Courtship Dance of the Medlpa, New Guinea.' Behaviour 58 (3): 298-316. doi.org/10.1163/156853976X00208.

Ross, William A. 1936. 'Ethnological Notes on Mt. Hagen Tribes (Mandated Territory of New Guinea), with Special Reference to the Tribe Called Mogei.' Anthropos 31: 341-63.

—_. 1937. 'Ordinary Month ... Extraordinary Mission.' The Christian Family and Our Missions 32: 66-68, 75.

Schulman, Ari N. 2015. 'The Man Who Helped Make Harper Lee.' The Atlantic (14 July). www.theatlantic.com/entertainment/archive/ 2015/07/maurice-crain-bonner-mcmillion-harper-lee-to-kill-amockingbird-go-set-a-watchman/398483/.

Seal, Mark. 2013. 'To Steal a Mockingbird?' Vanity Fair (31 July). www.vanityfair.com/culture/2013/08/harper-lee-dispute-royalties.

Souter, Gavin. 1964. New Guinea: The Last Unknown. London: Angus and Robertson. 
Spinks, Ken L. 1936. 'The Wahgi River Valley of Central New Guinea.' Geographical Journal 87 (March): 222-25 + map. doi.org/ $10.2307 / 1786762$.

Stewart, Pamela J., and Andrew Strathern. 2002. Gender, Song, and Sensibility: Folktales and Folksongs in the Highlands of New Guinea. Westport: Praeger.

Strathern, Andrew. 1985. "'A Line of Boys": Melpa Dance as a Symbol of Maturation.' In Society and the Dance, edited by Paul Spencer, 119-39. Cambridge: Cambridge University Press.

Strathern, Andrew, and Marilyn Strathern. 1971. Self-decoration in Mount Hagen. Art and Society Series. London: Gerald Duckworth and Co.

Taylor, James L. 1933. 'Mount Hagen Patrol, 27 March-19 October 1933.' 225 pp. National Archives of Australia A 7034, microfilm reel 7, item 218 .

Ticker, Neely. 2015. 'To Shill a Mockingbird: How a Manuscript's Discovery Became Harper Lee's “New" Novel.' The Washington Post (16 February). www.washingtonpost.com/lifestyle/style/toshill-a-mockingbird-how-the-discovexry-of-a-manuscript-becameharper-lees-new-novel/2015/02/16/48656f76-b3b9-11e4-886bc22184f27c35_story.html.

Vicedom, Georg F. 1937. 'Ein neuentdecktes Volk in Neuguinea: Völkerkundliche Beobachtungen an der Bevölkerung des HagenBerges im ehemals deutschen Teil von Neuguinea.' Archiv für Anthropologie 24: 11-44, 190-213.

Vicedom, Georg F., and Herbert Tischner. 1943-48. Die Mbowamb: Die Kultur der Hagenberg-Stämme im östlichen Zentral-Neuguinea. 3 vols. Monographien zur Völkerkunde. Vol. 1: Hamburg: Cram, de Gruyter, 1943-48; Vol. 2-3: Hamburg: Friederichsen, de Gruyter, 1943.

Williams, Francis E. 1937. 'The Natives of Mount Hagen, Papua: Further Notes.' Man 37: 90-96. doi.org/10.2307/2790755. 
This text is taken from A Distinctive Voice in the Antipodes: Essays in Honour of Stephen A. Wild, edited by Kirsty Gillespie, Sally Treloyn and Don Niles, published 2017 by ANU Press, The Australian National University,

Canberra, Australia.

dx.doi.org/10.22459/DVA.07.2017.15 